\title{
\begin{tabular}{l|l} 
Mibraries & DSpace@MIT
\end{tabular}
}

\author{
MIT Open Access Articles
}

Design for Micro-Enterprise: An Approach to Product Design for Emerging Markets

The MIT Faculty has made this article openly available. Please share how this access benefits you. Your story matters.

Citation: Austin-Breneman, Jesse, and Maria Yang. "Design for Micro-Enterprise: An Approach to Product Design for Emerging Markets." Volume 5: 25th International Conference on Design Theory and Methodology; ASME 2013 Power Transmission and Gearing Conference (August 4, 2013). () 2013 ASME International

As Published: http://dx.doi.org/10.1115/DETC2013-12677

Persistent URL: http://hdl.handle.net/1721.1/109217

Version: Final published version: final published article, as it appeared in a journal, conference proceedings, or other formally published context

Terms of Use: Article is made available in accordance with the publisher's policy and may be subject to US copyright law. Please refer to the publisher's site for terms of use. 
August 4-7, 2013, Portland, Oregon, USA

DETC2013-12677

\section{DESIGN FOR MICRO-ENTERPRISE: AN APPROACH TO PRODUCT DESIGN FOR EMERGING MARKETS}

\author{
Jesse Austin-Breneman* \\ Department of Mechanical Engineering \\ Massachusetts Institute of Technology \\ Cambridge, MA 02139 \\ Email: jlab@mit.edu
}

\author{
Maria Yang \\ Department of Mechanical Engineering, \\ Engineering Systems Division \\ Massachusetts Institute of Technology \\ Cambridge, MA 02139 \\ Email: mcyang@mit.edu
}

\begin{abstract}
Product design for emerging markets in the developing world is a rapidly growing field due to a steadily increasing market and an interest in profitably transforming consumer quality of life for this population. Economic and cultural barriers as well as other constraints present a daunting challenge for designers working in this area. This study documents current best practices and proposes a framework for future designers with a focus on creating products that foster micro-enterprise. These guidelines are drawn from existing literature and interviews with practicing designers of products for emerging markets. Four case studies are presented ranging across several product categories.
\end{abstract}

\section{INTRODUCTION}

Recent literature has focused on strategies for product growth opportunities in emerging markets [1-3]. Mature markets in industrialized countries have led Multi-National Corporations (MNCs) to look for growth in these areas. Although individual consumers in these markets have extremely limited buying power, the sheer size of the market makes these opportunities attractive to a variety of organizations. Prahalad estimates that the 4 billion people who have an income of $\$ 2$ or less a day represent approximately 5 trillion in purchasing power parity [4]. Nongovernmental Organizations (NGOs) have traditionally worked in this sector and continue to develop products aimed at improv-

*Address all correspondence to this author. ing the quality of life for this segment of the population. Social entrepreneurs such as International Development Enterprises have also been developing products specifically for these markets [5]. The increase in product development for these markets has been driven by "the potential of serving an unserved market and alleviating the level of global poverty while still earning a profit [6]." These organizations have been chiefly concerned with finding new strategies for delivering consumer goods and services to users in these markets. For example, many MNCs are currently using a "single-serve" distribution model where goods are packaged in small quantities for cash-constrained consumers $[4,7]$.

Many methodologies have been developed by practitioners and researchers in this field to create these products, including customer value chain analysis [8], design for the base of the pyramid (BoP) [9], the product service system approach [3], design for sustainable development [10] and design for emerging markets $[11,12]$. Both Pralahad and Chavan explore the different ways the market can be divided and how the strategies differ in perspective and target user $[4,12]$. Regardless of strategy used, there is a dearth of successful products in this area and many high-profile failures. One study reports that less than half of companies entering these markets meet their own goals [13]. This can be compared to a new product failure rate at launch of $33 \%$ in mature markets [14]. Other literature has also pointed to mixed results from MNCs working in emerging markets, with many operating at a loss [6]. 
Product failures can be attributed to many factors, but design literature points to a fundamental misunderstanding of the users $[1,12]$. This type of failure is common, perhaps as Bonsepe suggests inevitable, during remote design when the users are geographically separated from the designer $[15,16]$. For example, Kellogg's attempted to introduce breakfast cereal to the rural Indian market, assuming that Indian consumers would use cold milk. It failed to anticipate the breakdown of user experience when the cereal was eaten with warm milk [12]. Another failure mode is a misjudgment of the balance between affordability and quality. Many consumers in these markets are extremely price-conscious due to limited finances, but have been shown to pay more for a quality product than risk financial loss due to product failure [11]. The use of a "global" platform or product designed without regard to local market needs is another common failure mode. Whirlpool's world washer, a single washingmachine platform meant for all emerging markets, did well in many markets, but failed in India because the tolerances between the rotating drum and the case destroyed the thin layers of cloth common in Indian clothing [12].

Recent business literature suggests meeting unmet needs among micro-entrepreneurs, who represent a large segment of the population, may be the best strategy for operating in these markets $[17,18]$. Micro-enterpreneurs are individuals who generate small amounts of income from their own business activities, often in an informal market sector [19]. Karnani estimates there may be limited profit potential among consumers in emerging markets due to the cost of reaching heterogenous and distributed customers and their low to non-existant discretionary income [7]. London highlights how a focus on micro-entrepreneurs can create a positive value feedback loop between an organization and the entrepreneur and lead to more sustainable development [19]. The organization's product empowers the entrepreneur to generate more revenue and in turn, buy more products from the organization. In this vein, London further investigates the constraints facing BoP producers and how different ventures addressed these constraints [19]. Pitta provides an overview of the main threads in this discussion as well as case studies supporting this strategy [6]. This literature, as well as the observations and analyses of the case studies presented in this paper, demonstrate an important unmet user need for products among micro-entrepreneurs in emerging markets.

This paper proposes a set of guidelines called Design for Micro-enterprise (DfME) and seeks to respond to many of these criticisms by linking observations from successful products with insights from business literature. In design methodology literature, each structured method has an overarching principle and perspective which informs design decisions. The abovementioned strategies share a target market and the goal of alleviating global poverty. A gap in the design methodology literature is that these strategies view the user as a passive consumer. DfME is framed around understanding the end-user as a micro-entrepreneur. The process therefore transforms from a traditional Business to Consumer (B2C) transaction to a Businessto-Business (B2B) transaction; from a consumer to a commercial product [20]. While this transition limits the type of products that can be designed, it helps address many of the obstacles facing designers in this field by focusing the design process on building a long-term relationship with the user and supporting their income generation. The approach presented in this paper is meant to help the designer evaluate design ideas with this perspective in mind.

A unique distinction of $\mathrm{B} 2 \mathrm{~B}$ markets is that the relationship between the two enterprises is paramount. Every transaction is aimed at maintaining and improving this relationship; thereby growing the manufacturer's brand. In that vein, literature has shown that service contracts and guarantees become increasingly important in a commercial product [21]. Quality control has also been shown to be important for B2B and brand management [22]. Educating and interfacing with the enterprise client in an effective way when explaining the value proposition is another requirement for strong brand growth [21]. These factors contribute to establishing a strong positive brand identity in the market. Another insight from the business literature is to focus on income generation. Can the product generate revenue for the micro-entrepreneur? Dowling notes that B2B relationships "are designed on the understanding that each party contributes to the commercial success of the other [23]." This is especially important for micro-enterpreneurs whose resources are tightly constrained $[4,5]$.

DfME incorporates these insights with lessons drawn from the four case studies presented in this report to formulate a single approach. The guiding philosophy is to build brand identity by designing a product that increases the income of the micro-entrepreneur and supports a service plan that continues and grows the relationship between the micro-entrepreneur and your company.

\section{Related Literature}

Design for Micro-enterprise is a structured design process methodology, which draws from a rich Design for " $X$ " (DfX) literature. Holt and Barnes provide an overview of a range of DfX methodologies including Design for Assembly, Design for Manufacture and Design for Environment [24]. Design for the BoP and related methodologies are a subset of DfX meant to help designers create products that sustainably improve the livelihood of people who do not have their needs met [15]. Similar strategies, which have the same goal but approach it from different perspectives, include the Product Service System approach [3], Design for Extreme Affordability [25] and Design for the Bottom of the Pyramid $[12,26]$.

Due to its focus on entrepreneurship, Design for Microenterprise also incorporates lessons from business literature. In particular, DfME highlights the differences between B2B and 
$\mathrm{B} 2 \mathrm{C}$ transactions as a way to evaluate design decisions. $\mathrm{Mu}-$ dambi demonstrates how service and branding are important to B2B markets in differentiating competitors [22]. Lam makes a similar connection between service and customer loyalty in B2B [27]. In fact, intangible characteristics such as customer perception of service quality and brand image have been shown to be more important than product features in some B2B situations [21]. Less has been written specifically about B2B transactions in emerging markets, but service has been cited as an important strategy for companies looking for an advantage in emerging markets $[1,4]$.

Donaldson raises concerns over the focus in Design for the BoP on early stage design and not on distribution, manufacture or service of the products [15]. These factors may ultimately have more of an impact on the success of the product. The use of remote design and short-term consultancies has also been criticized [16]. Although these practices are prevalent throughout the field, they make it difficult to practice user-centric design, especially in a cross-cultural setting.

Design for Micro-enterprise seeks to address these critiques by integrating lessons from B2B markets. Shifting the focus from a consumer product to a commercial relationship also addresses many of the concerns raised about the original design methods in this area. DfME is meant to be practiced in a design team where design decisions support both user-centered design as well as business requirements such as service, distribution and production. The guidelines are intended to help the designer collaborate with the business and logistical members of the team and produce concepts with a higher chance of success in emerging markets.

\section{Methodology}

This study consists of two parts. First, insights from literature and interviews with four professional designers who work specifically designing goods for emerging markets are synthesized to present a framework for succesful product design in these areas. Second, the framework is explored against four case studies. The cases were selected along two criteria. The products had to have documented success in emerging markets and be at least partially used by micro-entreprises. The case studies represent a variety of product types, markets and company profiles and include some products and systems traditionally thought of for an individual user rather than for micro-enterprise (income generating for the consumer). The report uses the case study method described by Yin [28].

The goal of each case study is to gain insight into the strategies used by designers of successful products for emerging markets and use this to revise the framework. The four cases presented are the Nokia line of cell phones for emerging markets, a range of solar lamp products, several drip irrigation systems from India and two improved cookstove solutions. In each case study, the market for the product is analyzed. Contextual information about the product and manufacturer is also presented. Although performance metrics such as sales numbers were examined, it is difficult to gain independent confirmation of the numbers represented by the organizations themselves [15]. Instead, our analyses of these companies focused on whether the products were successfully sold on the market and which DfME guidelines, if any, were met. Metrics such as size of the company, type of company, location, and company age are presented to give a more complete picture of the product development environment. Product features are then compared to the DfME framework. Two alternative strategies for product success, Design for Cost and Identifying a good business opportunity, are examined with respect to each case $[14,25]$. These two alternative strategies were applied because they are commonly used in emerging markets and they contrast with DfME in terms of focus. We expect these alternatives to highlight DfME's strengths and shortcomings. Finally, design strategies drawn from the case examples are summarized.

The final DfME guidelines, which synthesize business insights, designer insights and include lessons learned from the case studies, are then presented. These are meant to be used by future designers as one approach when considering products of this type for emerging markets.

\section{Design for Micro-enterprise}

The interviews with the four practitioners highlighted strategies that they believed were important to consider when designing products for emerging markets. The main conclusion from the interviews was that the design choices should support the business plan of the end-user. As one designer noted, "income is the best 'hook' for a product, meaning customers are most likely to buy products they can see will help them generate income. DfME is a specific application of user-centric design where the user is a micro-entrepreneur in an emerging market. The guidelines are all within the context of gaining a deep understanding of the users needs. The guidelines are meant to focus the designers questions and strategies around the complex challenges facing these users.

Guideline 1: Design for the Entrepreneur's Business Plan The first and most important guideline is to design for the entrepreneur's business plan. Implicit in this guideline is that the designer must have a deep understanding of the needs of the user not only as a consumer but also as a microentrepreneur. Several strategies were described by the designers as ways to achieve this goal. Revenue Generating: The first is to make revenue generation central to the functionality of the product. This revenue generation should be clear, easily explained and understood by the end-user. Is it clear how to make money 
using the product? For example, power metering in several solar systems currently on the market allows micro-grid operators to accurately charge their customers. Upgradable: The second strategy is to design the product to accommodate different user needs as the business grows with time [29]. The product should have the ability to increase its performance capacity as the entrepreneur's business and capital grow. Can you size the product appropriately for your business and then easily grow it later? For example, a farmer buying a drip irrigation system can buy a small system and then later buy add-ons to increase its capacity without buying a whole new system.

\section{Guideline 2: Establish a Reliable Brand Identity} The second guideline revolves around establishing a positive brand identity associated with reliability. A positive service relationship is imperative to the relationship between the entrepreneur and manufacturer. The entrepreneur relies on the product and has a low tolerance for product failure [12]. The interviewed designers related two main strategies for avoiding product failure. Design for Reliability: One method is to design a robust product with a long expected life-cycle which does not need to be serviced very often. This can be done through material selection, component selection and simplification of the system. A rich body of literature describes similar strategies under Design for Reliability [30]. Design for Maintainability: Another strategy is to design the product so it can be serviced locally. Organizations utilize methods such as standardized parts and easy to disassemble systems. Okogbaa and Otieno provide an excellent overview of other strategies in Design for Maintainability [31].

Guideline 3: Consider Multi-functionality The final guideline is to consider multi-functional or convergence products [32]. Practitioners reported that the use of this strategy is highly dependent on the particular market and product type. For some markets and product types, such as solar lanterns, multifunctionality was seen as key to a product's success. The solar lantern was more desirable to the consumer with the ability to charge cell phones [33]. However, multifunctionality can lead to performance trade-offs. A Swiss army knife has many blades but none cut as well as a single purpose-designed knife. This strategy would be much less useful for agricultural processing products such as a wheat thresher. Despite this limitation, the existence of a number of counter-intuitive examples suggest that designers should consider if it is useful to the end-user to include additional functions in their product aside from the core functionality.

These guidelines are meant to suggest which strategies or perspectives are most important when designing for emerging markets. In short, DfME suggests that income generation, serviceability and then multifunctionality are the key aspects, in that order, for product success in emerging markets. Although there are many alternative strategies, several of which are presented above, we will be comparing DfME to Design for Affordability which focuses on minimizing the retail price point of the product.

\section{Results \\ Case Study 1: Nokia Emerging Market Cell Phones}

The Nokia line of cell phones has been cited as an exemplar of successful product and business strategy in emerging markets, with approximately $35 \%$ of their total sales in 2009 coming from emerging markets [11]. Many phones in these markets are used by micro-entrepreneurs. These phone owners generally operate as a mobile pay phone, renting out their phone to others in the community to make calls when infrastructure lacks other communication means. Figure 1 shows the Nokia 1200, one of the most popular entry-level phones sold in emerging markets [34]. The dominance of the Nokia phone in these markets is a good example of how the guiding principles of Design for Micro-enterprise can be implemented. Although this case study will focus on the features and business innovations that impact micro-entrepreneurs, the design of the cell phones was within the context of user-centric design. Nokia invested heavily in understanding the local users' needs. They established design centers in the emerging markets they were targeting [12]. This effort allowed them to gain a competitive advantage over both MNCs, such as Motorola, as well as local cell phone manufacturers. During the time period from 2005 to 2009 , Motorola produced a line of phone with same price points as Nokia which fared poorly and led to Motorola falling to fourth in many of the emerging markets [11].

In designing their line of phones for emerging markets, Nokia focused on building a strong positive brand identity associated with reliability. In an interview Antti Kujala, the lead designer for entry-level phones, said Nokia wanted to "avoid the look of 'cheaper'...boxes that look very brittle and lack robustness [34]." A dust-repellent keyboard, higher-quality materials and an easy-grip back designed for high-humidity environments are examples of design decisions driven by reliability concerns $[11,34]$. One user interviewed explained that all of his family used Nokia phones because, "You can drop it on the ground many times and it still works [35]." The company also made servicing their phones easier by sharing components among different models and having fewer components than competing models [36]. Nokia also invested heavily in building a distribution and retail network which doubled as a service network. For example, it uses a fleet of dedicated vans to reach rural Indian customers for both marketing and service work [36]. Nokia has also invested in building relationships with independent retailers to further grow their distribution and service network [11]. In summary, Nokia maintains a strong brand identity in emerging markets. It produces a high-quality product that is reliable in local conditions, investing in local technicians and distributors as well 
as its own network when needed.

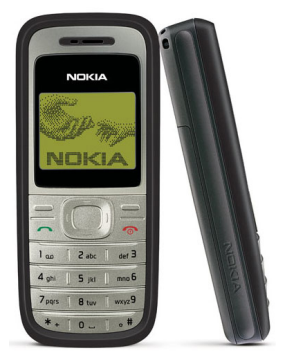

FIGURE 1. The Nokia 1100, one of the most popular entry-level phones sold by Nokia.

Nokia also utilized a multi-functional strategy with their phones. According to Kujala, the change in paradigm from a single-owner phone to a shared-use phone was pivotal in their design process [34]. The Nokia phones feature multiple contact lists which make it easy for users to share the same phone and keep their contact lists separate [12]. The phones are also equipped with a one-touch LED flashlight. The phones are also often equipped with a radio receiver. These features, especially the flashlight, are cited as a major advantage over competing models and a driving force behind Nokia's No. 1 position in emerging markets [11].

Nokia did an excellent job of educating potential customers about their products and how the phones can be used by microentrepreneurs. Nokia includes 80 languages in its user interface, meaning in situations where there are multiple local languages any user can easily interact with the phone [12]. The phone features a demo mode to familiarize the user with the operation of the phone. Nokia also developed "eRefills", a prepaid usage tracker which displays the exact amount and price of the airtime used in each call [11]. This metering is useful when charging customers per call. The multiple address books are also useful for the entrepreneur as a service provided to repeat customers. Without this business model, many of Nokia's users in emerging markets would not have been able to afford the phone [11].

Although Nokia made efforts to reduce the retail cost of the phone, many of their design decisions suggest that they were not making the cheapest possible phone. These decisions include their material choice, the effort to avoid a cheaper look, and the final cost which is a significant portion of their target market's income. In this case, another compelling alternative is that mobile phones are simply so useful in these markets, the demand for the ability to communicate is so high, that these design decisions did not affect consumers' choices. Customers would buy the phone regardless of the material selected or whether it supported their business. However, this theory does not explain why Nokia is so dominant compared to other cell phone providers.

Nokia was able to achieve and maintain the Nokia 1100's number one position in emerging markets from 2003 to 2010 by utilizing an understanding of their customers, supporting microenterprise activities and by providing a high-quality phone with locally available service. One aspect not covered in the original formulation of the DfME guidelines is the importance of educating the end-user on how the product can support their business. This will be incorporated into the following case studies.

\section{Case Study 2: Solar Lighting Technology}

According to a joint International Finance Corporation and World Bank report, 590 million people are not connected to their national electrical grid in Africa alone. Many users rely on flamebased technologies, such as paraffin lamps, for lighting [33]. Driven by this large potential market, solar lighting technology has become a rapidly growing field for emerging markets. Companies such as D. Light Design, Greenlight Planet, and Nokero have all produced solar lighting solutions aimed at this market. Their user base includes many entrepreneurs who either use the lights to support their business; keeping their shop open later at night, advertising their shop or using the lights to charge cellphones for a fee [33]. Although these companies utilized different strategies, their shared goal was to provide reliable lighting in off-grid situations. Many other companies have also focused on using solar technology for electricity generation in these markets. Although these technologies can also be considered solar lighting solutions, this case study will focus solely on products whose primary focus is lighting; specifically those shown in Figure 2, the D.light S10, Greenlight Planet Sun King Pro, and the Nokero N200 [37-39].

This case study will highlight issues which came up repeatedly in the two interviews with designers working on solar lighting products. The first is the durability of the product and how it relates to product branding and customer acceptance. The second is the desire for multi-purpose functionality in the lighting solution, especially as it applies to entrepreneurs. The third is the importance of educating the consumer about the value proposition and embedding that in the functionality of the product. Finally, the issue of affordability is addressed.

Product reliability was highlighted as a foremost concern in both designer interviews and market research. Lighting Africa found that "lack of trust in product quality and credibility of manufacturer's claims" were major deterrents for potential customers. Customers interviewed were highly risk-averse to product failure [33]. Designers mitigated concern about product failure through a focus on durability and longevity. This was demonstrated in several ways including feature selection, marketing and service networks. The material and feature selection of many of products offered in this area focus on durability. The technical specifications for all of the products highlighted their resistance 


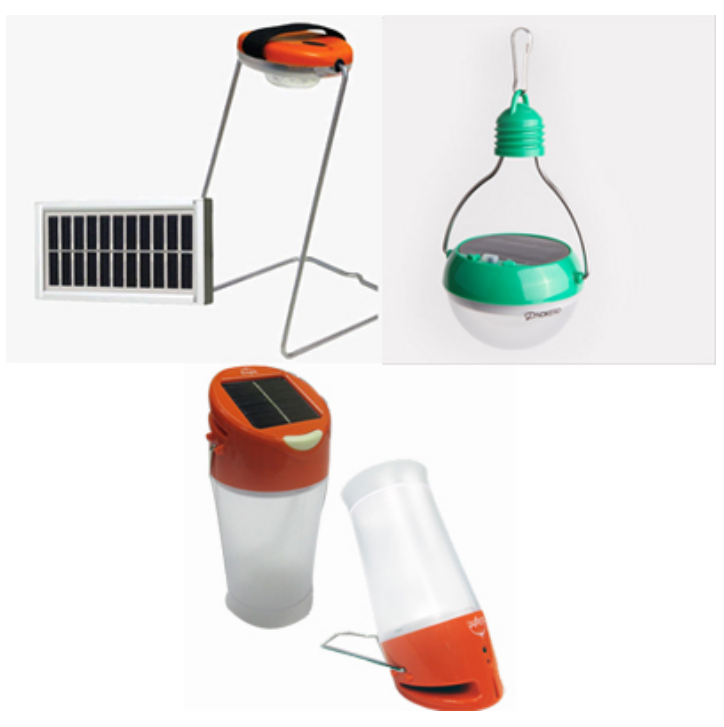

FIGURE 2. Clockwise from top left: Greenlight Planet Sun King Pro, Nokero N200, D. Light S10

to breaking. For example, the Sun King Pro lamp offers "unbeatable solar panel durability" with a strengthened glass panel face [38]. The d.light S10 features rain-resistant housings [37]. The N200 is "durable," and "rainproof [39]." Long product life cycles are also emphasized. The Sun King highlights its expected battery life of 5 years [38]. The S10 has "robust circuitry for long-life performance [37]." Several of the products also feature active battery protection to prevent deep discharging and overcharging and enhance battery life. Another strategy was to focus on the serviceability of the product. The S10 has an easily replaceable battery. The Sun King has a repairable junction box. Several of the products have a 1-year product warranty for the end-user.

Users also preferred having a multi-functional product. The Lighting Africa survey respondents strongly preferred multipurpose lighting solutions because they "only have one or two lighting devices but more places to light [33]." Microentrepreneurs interviewed had a marked preference for multifunctional lighting products. They desired many more lit locations than other respondents, including the till, storerooms, product shelves and storefront. Companies responded by incorporating several different use cases into their product. All of the products analyzed here feature handles which function as stands and hooks for different lighting needs. The products can be used and are marketed as task lighting, flashlights for mobile lighting, and lanterns/lamps for indoor lighting. The Sun King also charges cell phones. This was seen by designers in different markets a variety of ways. Some users rented out the cell phone charging feature to generate income. In other markets, cell phone charging was reported as being used as a convergence product by single users. One company which started out pursuing a solar lantern design switched to simply solar charging as users highly valued this feature.

The Lighting Africa report concluded that "educating the consumer is very important. ...[Companies] must make buyers aware of the problems that they are facing and how the new lighting devices overcome [them] [33]." The report emphasizes teaching users about savings in operating costs, ancillary benefits to education and the impact on escaping poverty. This is especially true for micro-entrepreneurs, who spent more on lighting than the average user [33]. One educational strategy was to focus marketing on savings gained by switching from kerosene or paraffin to solar energy. All of the products mentioned this is their promotional literature. Another strategy was to make the devices very easy to use and thereby eliminate the need to explain how the product solves the user's needs. All three devices have minimal connectors, one for connecting to the solar panel and possibly another for charging phones, and simple on-off switches and brightness controls. The Sun King Pro addressed this issue using feedback monitoring systems. The Sun King has an LCD display the amount of operating time left in the battery and also a charging indicator for help placing the solar panel.

Finally, the issue of affordability is a major concern in emerging markets. Although some strategies emphasize lowering the price point as much as possible, both designers and the Lighting Africa report highlighted that lowering the price point should not be done at the expense of durability or performance. The willingness to pay increased five to ten times between hearing the initial idea of a product and holding the physical product. "Consumers . . . quickly recognize and respond to the value proposition [solar lights] present once they have more information [33]." The products range from $\$ 15-25$, a large portion of the average \$125 monthly income for a family of four in the Lighting Africa survey. These companies have found success at these relatively high price points by offering quality durable products and focusing on brand management. For example, d. light had sold over 220,000 units by the end of 2010. This is encapsulated in user responses to what constitutes an ideal lighting product. Respondents indicated that the ideal lighting product "should be made by a reputable manufacturer in order to increase consumer confidence . . . indicating the value of building up brand recognition. [33]"

An affordable price point is, as demonstrated above, a critical part of the success of any solar lamp. Howeveer, the market research shows that these lamps are finding success at a relatively high price point. It is possible that any solar light would be successful in this area due to high demand. However, many solar solutions are not successful and kerosene lamps continue to dominate the market. The lamps covered in this study have been able to overcome the familiarity and popularity of kersone lamps by focusing on income benefits and adding multifunctional elements such as phone charging. Also many companies offer cheaper al- 
ternatives, including the lower end of the product family from d.light. The relative success of the models which include phone charging, use more robust materials and have better performance does not fit the Design for Cost model.

Companies and designers in the rapidly growing solar lighting market have utilized strategies focusing on the durability, reliability and multi-purpose aspects of their products. Several forprofit start-ups have found considerable success in this space by emphasizing the value proposition in their product and empowering micro-entrepreneurs to make income using their product.

\section{Case Study 3: Drip irrigation in India}

Drip irrigation is the practice of delivering small amounts of water directly to the base of each plant in a field using a system of tubes with small emitters at each plant location. Originally developed for large-scale agriculture in arid climates such as Israel, it has recently been the focus of many small-scale farmers in emerging markets [40]. These systems have many advantages over other irrigation schemes, especially in areas where water management is a crucial issue. Drip irrigation has grown rapidly in India, driven by both government programs aimed at improving water use efficiency and by the increases in crop yield using this method [41]. There are a variety of organizations who have developed products for this market. Large domestic corporations such as Jain Irrigation Ltd, MNCs such as John Deere and Netafim, non-profits such as International Development Enterprises India (IDEI), and small start-ups such as Driptech are all targeting small farmers in this area. These companies are seeing explosive growth in these product areas. For example, Jain Irrigation Ltd.'s revenue from micro-irrigation products has quadrupled from 2007-2011 and accounts for over half of its total revenue [42]. This case study will examine several of these products, specifically the Jain micro-irrigation range of products (shown in Figure 3), the IDEI KB drip system and the Driptech irrigation system. Interviews with designers regarding the strategies they used as well as market research regarding the impact of drip irrigation for small farmers will also be examined.

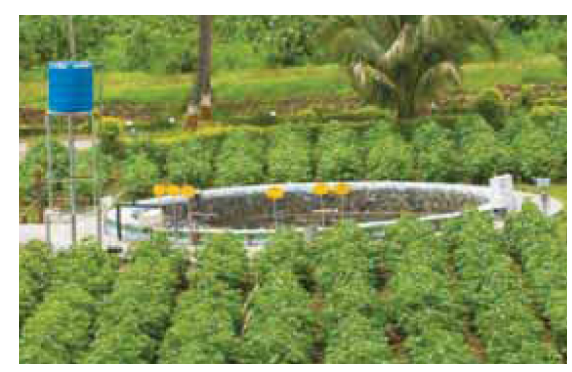

FIGURE 3. The Jain Irrigation Ltd. Micro-irrigation system [42]
The choice to focus on drip irrigation instead of other types of irrigation schemes, such as flood or sprinkler irrigation, was a major decision for many of the organizations in this area. This was highlighted in reports and the interview with a designer who led the development of a drip irrigation product for India. Several reasons were given for choosing drip irrigation, but the driving force was the total amount of income gained by using drip irrigation. As seen in Indian field tests on a variety of crops, drip irrigation has a positive impact on both crop yield and water savings $[40,41]$. Depending on the crop, the increase in yield is anywhere from $5-50 \%$ with most yields increasing $30 \%$ using 50-60\% less water. The ability to use these systems without access to electricity was another factor. Other systems require electric or diesel pumps that have larger operating costs. Drip irrigation technology was chosen due to its impact on the smallscale farmer's bottom line.

These systems support the entrepreneur's business in other ways as well. All of the systems are designed to be modular and expandable. The farmer can easily buy an appropriately sized system, adding more tubes for larger plots of land. In this way the farmer can also add capacity in the future when they have more capital without losing the original investment. The farmer can easily optimize the irrigation system for their farm. Other strategies include service networks that provide services outside of the irrigation system. For example, Jain Irrigation Ltd. provides both business and agricultural support free of charge to make sure that their systems have the greatest possible economic impact on their customers. IDEI collects market information on local high value crops and does cost-benefit analyses for their customers. They further support the farmers by identifying and enabling some local farmers to become nursery growers and micro-entrepreneurs selling sustainable farming materials to their community.

Serviceability was another concern brought up by the designer. The products addressed this issue in different ways. Driptech explicitly designed their system with fewer pieces, making it easier to maintain. Their system also replaced emitters located at the plant with precisely placed holes in the tubing. This choice reduces the amount of skill and tools needed to repair the system, allowing the farmer to perform the most common repairs. The Jain micro-irrigation system is more complex, but has a large local sales and service network. The design of their system focused on reliability. The system has filters and other mechanisms to prevent clogging of the emitters and increase the lifetime of the product.

IDEI chose a hybrid strategy with the KB drip system. It is designed to be highly customizable. The farmer can choose to use pre-punched hole, micro-tubes or button emitters as the water emitting device. The system can be operated using gravity or with a motor, diesel or electric. These choices represent a tradeoff between performance, complexity and cost. A farmer can easily switch to a more complex system if the need arises. IDEI also has a large system of local traders they use for sales and ser- 
vice. They also utilize the network of local micro-entrepreneurs they created to keep in contact with their users and get feedback.

Many irrigation systems focus on achieving the lowest possible cost due to the thin margins involved in small-scale agricultural production. However, the systems presented chose more expensive solutions, such as complex emitters, because of increased income benefits for the farmer. As there are many irrigation options open to each farmer depending on their situation, it is unlikely that this is a major unmet demand specifically for drip irrigation.

In conclusion, irrigation companies in India have achieved rapid growth through drip irrigations products and support services which focus on improving the revenue of small-holder farmers.

\section{Case study 4: Improved Cookstoves}

This case study compares two improved cookstoves, shown in Figure 4: the Protos Plant Oil Stove by Bosch and Siemens Home Appliances Group (BSH) and the Grameen Shakti Improved Cooking Stove (ICS). Grameen Shakti is a local NGO in Bangladesh which focuses on developing micro-entrepreneurs through technology. The Bosch and Siemens Home Appliances group is a MNC which was targeting rural consumers in Indonesia with the Protos. Although they were operating in different markets, both organizations' stated goal was to combat indoor air pollution caused by cooking on traditional stoves or open fires $[43,44]$. This is a driving force in the development of many improved cookstoves as indoor air pollution causes upwards of 1.5 millions deaths mainly in emerging markets [45].

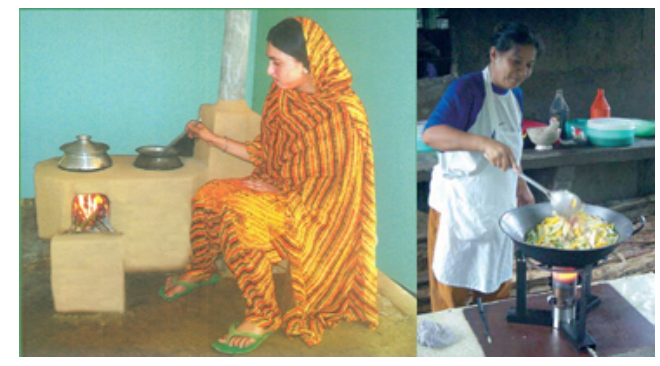

FIGURE 4. Right to left: Grameen Shakti ICS, Protos Plant Oil Stove

The Protos illustrates how consumer design goals can lead to sub-optimal outcomes. BSH stated that the goal in developing the Protos was to create a stove which was "high quality, safe and as easy as possible to use [44]." However the device also had to be "cheap enough for people in developing countries to be able to afford it [44]." This exemplifies common thinking during consumer product development, the tradeoff between quality and price matched as close as possible to consumer needs, but

without a clear understanding of the consumer's broader potential need for micro-enterprise. The product was tightly focused on cooking in the home, and therefore was not multi-functional. The design did not account for a local service network or have features intended to make it more robust. This was later identified by BSH as the most important factor in its lack of success. The Protos went through several field trials and was in series production in Indonesia before being discontinued due to lack of sales. BSH determined that the lack of an established market for plant oil and the increased time and effort to cook when compared to kerosene stoves were the two main factors in its lack of success.

The Grameen Shakti ICS took a different approach in its design. Grameen Shakti developed the ICS for use by microentrepreneurs such as restaurants and food production, in addition to consumer home use [43]. The product met all of the strategies listed in the guidelines. The stove is upgradable and available in several different sizes, from one to three mouth openings [43]. The ICS is also designed for service with much of the ICS manufacturing and repair occurring at a local level. The metal chimney and grates are manufactured at one of 45 Grameen Technology Centers and then the stoves are assembled and built locally. Grameen Shakti achieves this through a sales and service network they developed including 3,500 community technicians and entrepreneurs. This networks acts in conjunction with Grameen's extensive network of 1400 local offices tasked with linking the technology with income-generating activities. The ICS is also multi-functional with optional add-ons for soap manufacturing [43]. The ICS has been successful in this market with 391,000 units sold and installed since 2006 [46].

As this case study presents, the Grameen Shakti ICS was able to find success in the same product area as the Protos by focusing on supporting entrepreneurs and local service. BSH was unsuccessful despite the effort and resources spent on testing and developing the Protos stove. There are major differences between the two projects that may have contributed to the difference in success. First, Grameen Shakti, as a local NGO, may have a better understanding of user needs than BSH. Second, differences in the markets may have contributed to the results. $\mathrm{Ru}$ ral Bangladesh may be a better market opportunity than rural Indonesia. Finally, the distribution and service networks developed by Grameen Shakti certainly were a large factor in its acceptance by end-users. However, this highlights the differences in the designs. The ICS was set up to take advantage of local network and the Protos was not designed to be serviced by local technicians. It is unclear whether the local technicians had the knowledge or tools necessary to effectively repair the Protos stoves.

\section{Discussion}


TABLE 1. CASE STUDY COMPARISON

\begin{tabular}{|l|c|c|c|c|c|c|c|}
\hline Product & Org. Type & Org. Age & No. Employees & Location & Unit Sales & Price (\$) & Time on Market (yrs) \\
\hline Nokia 1100 & MNC & 148 & 100000 & Global & 200 Million & 90 & 9 \\
\hline D. Light S10 & SME & 6 & 100 & 43 Countries & 1.3 Millionn & 25 & 5 \\
\hline Nokero & SME & 3 & 6 & 33 countries & Not Availble & 15 & 2 \\
\hline Sun King Pro & SME & 5 & 350 & India, Africa & 3.5 Million users & 15 & 4 \\
\hline Driptech & SME & 5 & 30 & India & $>10000$ & $185 /$ acre & 4 \\
\hline IDEI KB Drip & NGO & 12 & 185 & India & $>250000$ & $148 /$ acre & 12 \\
\hline Jain & MNC & 50 & 7500 & India & $>500000$ & $370 /$ acre & N \\
\hline BS\&H Protos & MNC & 46 & 46000 & Indonesia & N/A & N/A & N/A \\
\hline Grameen ICS & SME & 1500 & 7500 & Bangladesh & 632000 & 10 & 7 \\
\hline
\end{tabular}

This paper proposes a new set of guidelines focused on developing commercial products for micro-entrepreneurs in emerging markets. The guidelines were drawn from interviews with four practicing designers and a literature analysis. These guidelines form a model for how product success can be achieved in these markets. This model emphasizes a focus on the entrepreneur's business plan, the relationship between the manafucturer and the micro-entrepreneur and multi-functionality over other factors. Several themes emerged from case studies. First, the guidelines are presented in order of importance. Revenue generation for the micro-entrepreneur was central to the product's success in all of the case studies. For example, in the drip irrigation case study, Jain Irrigation provided extra services free of charge to ensure their product generated additional income for their users. Although the case studies also highlighted how multi-functionality can have a positive effect on product success, its importance was highly dependent on the market. For example, in the cell phone and lighting case studies users placed a large premium on multi-functionality, but did not in the other examples. Second, educating the consumer about the value proposition was considered integral to product success. Companies in these case studies provided features or services that explained to potential customers how to generate revenue with their product. This was not explicitly indicated in the original formulation of the guidelines. Finally, alternative models for product success, such as Design for Cost and identifying good business opportunities did not fit these case studies well.

Although these alternative strategies are compelling in many ways, they were not appropriate for these cases. An affordable retail price is essential to product success in many markets. Lowering the price is one way to increase the value proposition of a product. However, the results from the case studies suggest that other factors are more important to product success, especially when designing for micro-entrepreneurs. All of the examples were able to achieve success at relatively high price points in the face of cheaper competitors. Identifying a good business opportunity is also critical to product success. If there is a high demand for your type of product, then this may outweigh other factors which affect product success. For example, if there is a high demand for mobile communication in a particular market, any cell phone might become successful regardless of design intent. This does not fit the examples presented above as similar products were not successful in the same markets.

As shown in Table 1, the case studies represent a wide range of organizations and products. Small, medium and large companies have all used the strategies presented to achieve success in these areas. These comparisons are meant to highlight the range of companies working in this area and give a sense of the context for the case studies, not to draw conclusions about which product is the most successful.

This study is limited by several factors. First, although the case studies presented represent a variety of markets and product types, the set is not exhaustive and may contain selection biases or errors. This is also true of the sales performance data, which was compiled from a variety of sources and represented a conservative lower bound of the number of units sold. Also, because the products have been on the market for differing lengths of time, this may be under-representing the success of newer products. Likewise, for many of the products there was no independent testing of the features or specifications listed by the manufacturers. Although this data existed and was used for the lighting products, the rest of the products were categorized primarily on the manufacturers' claims. Finally, a comparison of units sold across product categories is limited due to differences between product types. For example, a nutritional bar will have a much higher sales volume than an automobile for the same market. A better metric might be economic impact on the entrepreneur, but that type of data is difficult to determine. 


\section{Conclusion}

In conclusion, this paper proposes a new approach for product design for emerging markets called Design for Micro-scale Enterprise. This approach consists of three guidelines: Design for the Entrepreneur's Business Plan, Establish a Reliable Brand Identity and Consider Multi-functionality. These guideline were achieved through strategies such as design for reliability, design for maintainability, upragadeabilty and multi-functionality. As seen in the case studies, considerable success can be achieved in these markets by focusing on the unmet needs of microentrepreneurs.

\section{Future Work}

It is the authors' hope that this proposal furthers the discussion of best practices for product design in emerging markets. Future work will include two major threads. The first is to compile a more comprehensive list of products used in one particular emerging market and investigating trends in that data set. Building on current work by the Comprehensive Initiative on Technology Evaluation, future work will also consist of categorizing and understanding design decisions which affected the success of a product. The second thread will consist of examining the impact of this approach on education. Design classes focusing on emerging markets are a growing part of many engineering curriculae and incorporating best practices into these courses and investingating their effect will be paramount to producing engineers and designers able to work in a global future.

\section{ACKNOWLEDGMENT}

The work described in this paper was supported in part by the National Science Foundation under Award CMMI-1130791 and the Graduate Fellowship Program. We would also like to thank Sydney Carter for her thoughtful assistance. We would also like to thank the designers interviewed for theirvaluable feedback on many of the case study examples. The opinions, findings, conclusions and recommendations expressed are those of the authors and do not necessarily reflect the views of the sponsors.

\section{REFERENCES}

[1] Ramamurti, R., 2008. What Have We Leaned About EMNEs? Cambridge University Press, Cambridge, UK, ch. 13.

[2] SadreGhazi, S., and Duysters, G., 2009. Serving lowincome markets : rethinking multinational corporations strategies. Multinationals and emerging economies. Edward Elgar Publishing, Northampton, MA, ch. 10, pp. 166195.
[3] Schafer, C., Parks, R., and Rai, R., 2011. "Design for emerging bottom of the pyramid markets: A product service system (pss) based approach". In Internation Design Engineering and Technical Conferences.

[4] Pralahad, C., 2009. The Fortune at the Bottom of the Pyramid. Pearson Education, Upper Saddle River, NJ.

[5] Polak, P., 2009. Out of Poverty: What Works When Traditional Approaches Fail. Berret-Koehler Publishers, San Francisco, CA.

[6] Pitta, D., Guesalaga, R., and Marshall, P., 2008. "The quest for the fortune at the bottom of the pyramid: potential and challenges". The Journal of Consumer Marketing, 25(7), pp. 393-401.

[7] Karnani, A., 2007. "Misfortune at the bottom of the pyramid". Greener Management International, pp. 99-110.

[8] Donaldson, K. M., Ishii, K., and Sheppard, S. D., 2006. "Customer value chain analysis". Research in Engineering Design, 16, pp. 174-183.

[9] Whitney, P., and Kelkar, A., 2004. "Designing for the base of the pyramid". Design Management Review, 15(4), Fall, pp. 41-47.

[10] Ngai, T., Shrestha, R. R., Dangol, B., Maharjan, M., and Murcott, S. E., 2007. "Design for sustainable development - household drinking water filter for arsenic and pathogen treatment in nepal". Journal of Environmental Science and Health Part A, 42(12), pp. 1879-1888.

[11] Kang, K., place, M., and Seyler, D., 2009. "Developing new products for emerging markets: a competency based approach". Master's thesis, Rochester Insititute of Technology, Rochester, NY, November.

[12] Chavan, A. L., Gorney, D., Prabhu, B., and Arora, S., 2009. "The washing machine that ate my sari-mistakes in crosscultural design". Interactions, January+February, pp. 2631.

[13] , 2007. Innovation in emerging markets. Tech. rep., Deloitte Touche Tohmatsu.

[14] Cooper, R. G., and Kleinschmidt, E. J., eds., 2011. New Products: The Key Factors in Success. Marketing Classics Press.

[15] Donaldson, K., 2009. "The future of design for development: Three questions”. Information Technologies and International Development, 5(4), Winter, pp. 97-100.

[16] Fathers, J., 2003. "Peripheral vision: An interview with gui bonsiepe charting a lifetime of commitment to design empowerment". Design Issues, 19(4), Autumn, pp. 44-56.

[17] Hallberg, K., 2000. A market-oriented strategy for small and medium scale enterprises., Vol. 40. World Bank Publications.

[18] Redfern, A., and Snedker, P., 2002. Creating market opportunities for small enterprises: experiences of the fair trade movement. International Labour Office, Geneva, Switzerland. 
[19] London, T., Anupindi, R., and Sheth, S., 2010. "Creating mutual value: Lessons learned from ventures serving base of pyramid producers". Journal of Business Research, 63, pp. 582-594.

[20] Leek, S., and Christodoulides, G., 2011. "A literature review and future agenda for b2b branding: challenges of branding in a b2b context". Industrial Marketing Management, 40, pp. 830-837.

[21] Ballantyne, D., and Aitken, R., 2007. "Branding in b2b markets: insights from the service-dominant logic of marketing". The Journal of Business \& Industrial Marketing, 22(6), p. 363.

[22] Mudambi, S., 2002. "Branding importance in business-tobusiness markets: Three buyer clusters". Industrial Marketing Management, 31, pp. 525-533.

[23] Dowling, G., 2002. "Customer relationship management: In b2c markets, often less is more". California Management Review, 44(3), Spring.

[24] Holt, R., and Barnes, C., 2010. "Towards an integrated approach to "design for x": an agenda for decision-based $\mathrm{dfx}$ research". Research in Engineering Design, 21, pp. 123136.

[25] Falcioni, J. G., 2011. "Research in extreme affordability". Mechanical Engineering, 133(5), May, p. 6.

[26] Seghal, V., Dehoff, K., and Panneer, G., 2010. “The importance of frugal engineering". Strategy+Business, 59, Summer.

[27] Lam, S. Y., Shankar, V., Erramilli, M. K., and Murthy, B., 2004. "Customer value, satisfaction, loyalty and switching costs: An illustration from a business-to-business service context". Journal of the Academy of Marketing Science, 32, pp. 293-311.

[28] Yin, R. K., 2009. Case study Research: Design and Methods. SAGE Publications, Los Angeles, CA.

[29] , 2010. An Engineering Design Strategy for Reconfigurable Products that Support Poverty Alleviation.

[30] Crowe, D., and Feinberg, A., eds., 2001. Design for Reliability. CRC Press, Lowell, MA.

[31] Okogbaa, O. G., and Otieno, W., 2007. Design for Maintainabillity. Environmentally Conscious Mechanical Design. John Wiley \& Sons, Hoboken, NJ, ch. 6.

[32] Wang, Z., Kannan, P. K., and Azarm, S., 2011. "Customerdriven optimal design for convergence products". Journal of Mechanical Design, 133, October, pp. 101010-1.

[33] Baker, M., and Alstone, P., 2011. The off-grid lighting market in sub-saharan africa: Market research synthesis report. Tech. rep., Lighting Africa, Washington, DC, February.

[34] Lakshman, N., 2007. Nokia: It takes a village to design a phone for emerging markets.

[35] Tan, J., 2007. "Battle to the top". Forbes, November.

[36] Ewing, J., 2007. Nokia lesson learned, reward reaped.

[37] http://www.dlightdesign.com/product-line/s10.
[38] http://www.greenlightplanet.com/products.html.

[39] http://store.nokero.com/Crestone-Solar-Light-Bulbp/n200.htm.

[40] Postel, S., Polak, P., Gonzales, F., and Keller, J., 2001. "Drip irrigation for small farmers". Water International, 26(1), pp. 3-13.

[41] Kumar, D. S., and Palanisami, K. "Impact of drip irrigation on farming system: Evidence from southern india". Agricultural Economics Research Review, 23.

[42] Ltd., J. I. S., 2011. "24th annual report 2010-2011”.

[43] http://www.gshakti.org/index.php?option=com_content\&view =artic

[44] http://www.bsh-group.com/index.php?109906.

[45] Rehfuess, E., 2006. Fuel for life: household energy and health. Tech. rep., World Health Organization.

[46] http://www.pciaonline.org/grameen-shakti. 